\title{
Effect of refrigeration systems upon frozen bull sperm viability assessed by computer-assisted sperm analysis and fluorescent probes
}

\author{
Efeito de sistemas de refrigeração sobre a viabilidade do sêmen \\ bovino congelado analisado por meio de sistema computadorizado e \\ sondas fluorescentes
}

\author{
Marcelo George Mungai Chacur ${ }^{1 *}$; Huberson Sanches Dias ${ }^{2}$; \\ Patricia de Mello Papa ${ }^{3}$; Frederico Ozanam Papa ${ }^{4}$; Cely Marini Melo-Onã ${ }^{5}$
}

\begin{abstract}
Sperm cryopreservation success depends upon the maintenance of spermatozoa fertility potential. Sperm cells must preserve both integrity and functionality of several cell structures. The stabilization phase must allow the exit of water from the sperm cells via osmosis. This study aimed to compare the effect of refrigeration in the commercial refrigerator (CR) and the transport/refrigeration box (TRB) upon the viability of frozen bull sperm diluted in three different extenders (A, B and C). Ten Nellore bulls, Bos taurus indicus maintained in Artificial Insemination Center were used and the spermatozoa samples was assessed for Plasma Membrane Integrity and CASA evaluation. The stabilization phase $\left(5^{\circ} \mathrm{C} / 4\right.$ hours $)$ was performed in the $\mathrm{CR}$ as well as in the TRB, and then samples were exposed to nitrogen vapor during 20 minutes and then plunged into nitrogen. The statistical analysis was done using the variance analysis and the significance level was set at $5 \%$. In the CR the post-thawing parameters for PM and ALH were higher $(\mathrm{p}<0.05)$ in the extender A (glicine egg-yolk) and extender B (glicine egg-free) when compared with extender C (TRIS egg-yolk). As for BCF, STR and LIN, the parameters were higher (p $<0.05$ ) in extender B than in C. Samples that were stabilized in the TRB presented higher post-thawing parameters $(\mathrm{p}<0.05)$ for PM and LIN in extender A and extender B when compared with C. BCF and STR parameters were higher $(\mathrm{p}<0.05)$ in extemder B when compared with C. Extender B samples had higher $(\mathrm{p}<0.05)$ PMI when stabilized in CR. The findings in this experiment enable us to say that both $\mathrm{CR}$ and TRB were effective in keeping the viability of post-thawing bull semen.
\end{abstract}

Key words: Zebu bull, cooled semen, frozen semen, CASA, membrane integrity

\section{Resumo}

O sucesso da criopreservação do sêmen depende da manutenção do potencial de fertilidade dos espermatozoides. Nos espermatozoides deve haver a preservação da integridade e funcionalidade de várias das suas estruturas. A fase de estabilização permite a saída de água dos espermatozoides por osmose. Este estudo tem o objetivo de comparar o efeito da refrigeração em refrigerador comercial (RC) e em caixa de transporte refrigerada (CTR) na viabilidade do sêmen congelado bovino diluído em três diferentes meios (A, B e C). Dez touros Nelore, Bos taurus indicus mantidos em central de inseminação artificial foram utilizados e as amostras de sêmen analisadas para checar a integridade das

\footnotetext{
Prof. Universidade do Oeste Paulista, UNOESTE, Presidente Prudente, SP. E-mail: chacur@unoeste.br

Pesquisador, UNOESTE, Presidente Prudente, SP. E-mail: huber@hotmail.com

Discente, UNOESTE, Presidente Prudente, SP. E- mail: paty@hotmail.com

Prof. Universidade Estadual Paulista, UNESP, Botucatu, SP. E- mail: papa@fmvz.unesp.br

Pesquisadora, UNESP, Botucatu, SP. E- mail: cely@hotmail.com

Author for corespondence
}

Recebido para publicação 21/03/12 Aprovado em 15/08/12 
membranas plasmáticas e por meio da análise computadorizada (CASA). A fase de estabilização $\left(5^{\circ} \mathrm{C} / 4\right.$ horas) foi realizada em RC e em CTR, sendo as amostras expostas ao vapor de nitrogênio durante 20 minutos e após mergulhadas no nitrogênio. A estatística foi feita com a análise de variância com nível de significância a 5\%. No RC os parâmetros pós-descongelação para PM e ALH foram superiores ( $\mathrm{p}<$ 0,05) no meio B em relação ao C. Amostras que foram estabilizadas na CTR apresentaram parâmetros superiores $(\mathrm{p}<0,05)$ para PM e LIN nos meios A e B, em relação ao C. Os parâmetros BCF e STR foram superiores $(p<0,05)$ no meio B em relação ao C. As amostras do meio B tiveram maior $(p<0,05)$ PMI quando estabilizadas no RC. No presente estudo, conclui-se que o RC e a CTR foram efetivos na manutenção da viabilidade pós-descongelação do sêmen bovino.

Palavras-chave: Touros zebu, sêmen refrigerado, sêmen congelado, CASA, integridade de membrana

\section{Introduction}

The artificial insemination (AI) is probably the most important tool for the advance in the animal farming industry, and the sperm cryopreservation success adds advantages to the AI technique (FARRELL et al., 1998). A successful sperm cryopreservation depends upon the maintenance of the spermatozoa fertility potential, which means that they must present good integrity and functionality of several different cell structures (CELEGHINI, 2005).

The stabilization phase varies according to the animal species, freezing-thawing protocol, and the extender that is being used (CHACUR, 1996). Foote and Kaproth (2001) concluded that four hours of stabilization phase were sufficient to provide a good surviving rate for spermatozoa after the freezing/ thawing process.

When spermatozoa undergo a slow cooling process a high amount of water exits from the inside of sperm cells. On the other hand, if the cooling process is too fast it may not allow for the exit of water and thus ice crystal is formed within the sperm cells. A good cooling rate must allow the exit of water from spermatozoa but not in excess, in a way that some tiny crystals may be formed without being prejudicial to the cell in order to avoid cell death (GRAHAM, 1995). The cooling rate must be compatible with the water balance to establish efficient cryopreservation protocols (WATSON, 2000).
The Computer-Assisted Sperm Analysis (CASA) provides accurate information of several sperm movement parameters with more precise fertility estimation if compared to the parameters that are assessed by routine microscopy (FARRELL et al., 1996). The association of fluorescent probes to assess sperm membrane integrity enables the simultaneous evaluation of various sperm cells compartments (HARRISON; VICKERS, 1990; CELEGHINI, 2005). Effects of extenders on post thaw quality and fertility of bovine sperm (SCHENK; AMANN; ALLEN, 1987; FARRELL et al., 1996) and bubaline using Triladyl, glycine-egg-yolk and TES extenders was studied (CHACUR, 1996; CHACUR et al., 1997). This study aimed to compare the effect of refrigeration in the commercial refrigerator and the transport/refrigeration system upon the viability of frozen bull sperm.

It was collected semen samples of the ten Nellore bulls of an Artificial Insemination Center (AIC). All animals were in semen collection schedule in accordance with the AIC management. Only after verifying the homogeneity of qualitative and quantitative characteristics from all ten bulls ejaculates those samples were included in this experiment. In order to collect the ejaculates it was used an artificial vagina. Three traditional extenders were used in this study. The samples were diluted (1:1) with the fraction I from extender C (TRIS eggyolk), extender A (glicine egg-yolk), and extender B (glicine egg-free), and then were kept in a transport/ refrigeration container and taken to the laboratory (approximately 15 minutes of transportation). 
Qualitative and quantitative semen characteristics were verified (pre-freezing sperm parameters): volume $(\mathrm{mL})$, sperm motility $(\%)$, sperm vigor (1 to 5), sperm concentration $\left(\times 10^{6} / \mathrm{mL}\right)$, major defects $(\%)$ and minor defects (\%). Morphological sperm analysis was performed in a phase contrast microscopy.

Samples were aliquoted and added with $50 \%$ of total volume using the respective fraction II of each extender A, B and C (glycerol 13\%). They were standardized to a final concentration of $30 \times 10^{6}$ viable spermatozoa / straw, packaged into $0.5 \mathrm{~mL}$ straws and labeled as group CR (commercial refrigerator - R 360®, Electrolux) or group TRB (transport/ refrigeration box - Botubox ${ }^{\circledR}$, Biotech Botucatu). After packaging, straws were horizontally placed in a sieved steel tray and subjected to the stabilization phase in either commercial refrigerator (CR) or transport/refrigeration box (TRB) at $5^{\circ} \mathrm{C} / 4$ hours. Then, trays containing the straws were placed on an aluminum frame at $5 \mathrm{~cm}$ above liquid nitrogen level of a styrofoam box ( 51 x 45 x $45 \mathrm{~cm})$. Twenty minutes later straws were plunged into nitrogen and stocked in cryogenic container. When three days were gone, one straw from each treatment was thawed in water bath at $46^{\circ} \mathrm{C} / 20$ seconds. Semen was homogenized and subjected to microscopic analysis and total motility ( 0 to $100 \%$ ) was measured.

Frozen semen samples were transported in nitrogen tanks to perform the CASA. After thawing samples, one droplet of each sample was placed on a $38^{\circ} \mathrm{C}$ Makler chamber to perform the sperm analysis. The computer was set for bovine semen and the minimum of three randomly scanned fields were assessed. The following characteristics were analyzed: total motility (TM), progressive motility (PM), average path velocity (VAP), straightline velocity (VSL), curvilinear velocity (VCL), amplitude of lateral head displacement (ALH), beat cross frequency (BCF), straightness (STR), linearity (LIN) and rapid cells (RAP).
The Plasma Membrane Integrity analysis (PMI) was done using fluorescent probes named Carboxyfluorescein Diacetate (CFDA) and Propidium iodide (PI), in accordance with Harrison and Vickers (1990), diluting $10 \mathrm{~mL}$ of semen in $40 \mathrm{~mL}$ of work solution (1 mL sodium citrate $2.95 \% ; 10 \mu \mathrm{L}$ formaldeide; $10 \mu \mathrm{L}$ CFDA; $20 \mu \mathrm{L}$ $\mathrm{PI})$. The material was analyzed in a BW filter of an epifluorescence microscope (Nikon, E200, Japan) at a 400X magnification. Two hundred cells were counted and the ones that were tainted green were intact, and the ones that were tainted either red or red and green were damaged. The result was expressed in intact cells percentage. Post-thawing statistical analysis was done using the variance analysis. The significance level was set at 5\%.

Visual estimation of the percentage of motile spermatozoa is the most common laboratory test of sperm quality. The quantitative and qualitative semen characteristics are showed in Table 1. The $95 \%$ confidence interval is about \pm 20 percentage units for a single visual determination of the percentage of motile bull spermatozoa (DEIBEL et al., 1976).

The association of some characteristics such as motility percentage, number of spermatozoa with progressive motility, and the percentage of spermatozoa of normal morphology allows for a good fecundating capacity estimation of a sample (BAILEY et al., 2000; CHACUR; CASTILHO; GUABERTO, 2011). Even though the andrological selection may enable the selection of superior bulls, it does not mean that their semen shall be of good freezability since semen morphological characteristics have little influence upon the freezing process success (SALVADOR et al., 2008). 
Table 1. Pre-freezing sperm parameter in Nellore bulls in an Artificial Insemination Center.

\begin{tabular}{|c|c|c|c|c|c|c|c|c|c|c|c|}
\hline \multicolumn{2}{|c|}{ Motility (\%) } & \multicolumn{2}{|c|}{ Volume (mL) } & \multicolumn{2}{|c|}{ Vigor (0-5) } & \multicolumn{2}{|c|}{$\begin{array}{l}\text { Concentration } \times 10^{6} / \\
\mathrm{mL}\end{array}$} & \multicolumn{4}{|c|}{$\begin{array}{c}\text { Sperm morphology }(\%) \\
\text { Major defects } \\
\text { Minor defects }\end{array}$} \\
\hline $\begin{array}{l}\text { Bulls } \\
(\mathrm{n}=10)\end{array}$ & & $\begin{array}{l}\text { Bulls } \\
(\mathrm{n}=10)\end{array}$ & & $\begin{array}{c}\text { Bulls } \\
(\mathrm{n}=10)\end{array}$ & & Bulls $(n=10)$ & & $\begin{array}{l}\text { Bulls } \\
(\mathrm{n}=10)\end{array}$ & & $\begin{array}{l}\text { Bulls } \\
(\mathrm{n}=10)\end{array}$ & \\
\hline 70 & 80 & 7 & 10 & 3 & 4 & 2300 & 2026 & 4 & 10 & 19 & 4 \\
\hline 75 & 80 & 6 & 12 & 5 & 4 & 1821 & 2000 & 25 & 15 & 7 & 3 \\
\hline 80 & 80 & 6 & 9 & 3 & 5 & 1632 & 3060 & 10 & 7 & 17 & 6 \\
\hline 75 & 75 & 12 & 8.5 & 4 & 4 & 2804 & 1724 & 18 & 6 & 6 & 15 \\
\hline 75 & 70 & 4.5 & 5.5 & 4 & 5 & 1301 & 2965 & 7 & 14 & 7 & 5 \\
\hline
\end{tabular}

Source: Elaboration of the authors.

Although high initial sperm motility does not ensure a good freezing performance, it allows animals that have increased low motility rate in their samples to present post-thawing semen approvals (CHACUR, 1996; SALVADOR et al., 2008). One single laboratory test is not enough to evaluate semen fertility potential owing to the fact that it is necessary for a sperm sample to present several good characteristics to achieve a fecundating capacity (GRAHAM; KUNZE; HAMMERSTEDT, 1990; CHACUR et al., 2010). The use of CASA to assess various sperm movement characteristics, together with the determination of sperm viability through the cytoplasmic membrane analysis shall provide a better accuracy to the in vitro bovine semen evaluation (FARRELL et al., 1998).

As for the semen stabilization in both commercial refrigerator (CR) and transport/ refrigeration box (TRB) Table 2, the extender A (glicine egg-yolk) $70.4 \pm 6.4 \mathrm{~mm} / \mathrm{s}$ and extender B (glicine egg-free) $66.9 \pm 9.7 \mathrm{~mm} / \mathrm{s}$ presented higher $\mathrm{PM}(\mathrm{P}<0.05)$ if compared to extender $\mathrm{C}$ (TRIS eggyolk) $64.2 \pm 11.2 \mathrm{~mm} / \mathrm{s}$, when stabilized in the TRB. Whereas no difference $(\mathrm{P}>0.05)$ was found in the CR. Finding different motility in different extenders indicates that their components act in distinct sperm cell compartments, especially the ones that are involved in cell motility such as the plasma membrane integrity, integrity of tail structures and mitochondrial function (CELEGHINI, 2005). The movement pattern of spermatozoa is influenced by their external environment for example seminal plasma or extenders with different densities (MORTIMER, 2000).

Extender $\mathrm{A}(5.8 \pm 0.7 \mu \mathrm{m})$ and extender $\mathrm{B}(5.6 \pm 0.7$ $\mu \mathrm{m})$ showed better results for ALH if compared to extender $\mathrm{C}(\mathrm{P}<0.05)$, when using the $\mathrm{CR}$ whereas the TRB showed no statistical difference $(\mathrm{P}<0.05)$. Lower values to ALH are better to reduce the energy lost. The amplitude of lateral head (ALH) is the width of the lateral movement of the sperm head. It is calculated as the total width of the head trajectory (rather than half the width, which is the amplitude value used in physics and mathematics) and is expressed in micrometers (DAVID; SERRES; JOUANNET, 1981). The CASA provides sufficiently accurate data concerning the velocity and individual sperm movement that are highly related to fertility (FARRELL et al., 1998). The decrease in sperm velocity may be caused by high density of extenders due to the presence of large particles, and that may cause a decrease in $\mathrm{BCF}$ (MORTIMER, 2000). The BCF is expressed in hertz and is calculated by counting the number of times the curvilinear path crosses the average path per second (MORTIMER, 2000).

As for $\mathrm{BCF}$, extender $\mathrm{B}$ had better results $(\mathrm{P}<0.05)$ than extender $\mathrm{C}$ for both $\mathrm{CR}$ and TRB (CR: $31 \pm 3.7$ $\mathrm{Hz}$ versus $25.3 \pm 4.5 \mathrm{~Hz}$; and in TRB: $30.1 \pm 2.7 \mathrm{~Hz}$ 
versus $24.9 \pm 3.6 \mathrm{~Hz}$ ); better results were also seen for STR (CR: $83.7 \pm 3.9 \mathrm{~Hz}$ versus $76.9 \pm 4.6 \mathrm{~Hz}$; and in TRB: $82.8 \pm 4.1 \mathrm{~Hz}$ versus $76.2 \pm 5.4 \mathrm{~Hz}$ ). The BCF is a useful value in the estimation of gross changes in the flagellar beat pattern (MORTIMER, 2000).

When it comes to the LIN, the use of CR with extender $\mathrm{B}$ showed better results $(\mathrm{P}<0.05)$ if compared to extender $\mathrm{C}(55.7 \pm 5.2 \%$ versus $47.0 \pm 4.1 \%)$, whereas in the TRB the extender $\mathrm{A}$ $(53.1 \pm 6.5 \%)$ and extender B $(54.3 \pm 5.4 \%)$ had better results $(\mathrm{P}<0.05)$ than the extender $\mathrm{C}(46.3 \pm 5.4 \%)$. The velocity values that are determined are the curvilinear velocity (VCL), straight-line velocity (VSL), and average path velocity (VAP). The VCL refers to the total distance that the sperm head covers in the observation period and is always the highest of the 3 velocity values. The VSL is determined from the straight-line distance between the first and last points of the trajectory and gives the net space gain in the observation period. Linearity (LIN), LIN=(VSL/VCL) X 100 (MORTIMER, 2000).

Table 2. Bull frozen semen parameter averages and standard deviations after stabilization in both commercial refrigerator (CR) and transport/refrigeration box (TRB).

\begin{tabular}{|c|c|c|c|c|c|c|}
\hline & \multicolumn{3}{|c|}{$\mathrm{CR}$} & \multicolumn{3}{|c|}{ TRB } \\
\hline & Extender C & Extender A & Extender B & Extender C & Extender A & Extender B \\
\hline TM & $67.8 \pm 12.3^{\mathrm{A}}$ & $73.6 \pm 8.0^{\mathrm{A}}$ & $68.1 \pm 11.4^{\mathrm{A}}$ & $64.2 \pm 11.2^{\mathrm{B}}$ & $70.4 \pm 6.4^{\mathrm{A}}$ & $66.9 \pm 9.7^{\mathrm{A}}$ \\
\hline PM & $46.3 \pm 8.3^{\mathrm{B}}$ & $54.8 \pm 4.7^{\mathrm{A}}$ & $51.9 \pm 7.8^{\mathrm{A}}$ & $42.3 \pm 7.5^{\mathrm{B}}$ & $52.4 \pm 5.0^{\mathrm{A}}$ & $51.9 \pm 7.2^{\mathrm{A}}$ \\
\hline VAP & $97.4 \pm 13.0^{\mathrm{A}}$ & $89.7 \pm 11.0^{\mathrm{B}}$ & $93.6 \pm 6.1^{\mathrm{A}}$ & $101.3 \pm 13.3^{\mathrm{A}}$ & $88.1 \pm 11.7^{\mathrm{B}}$ & $95.9 \pm 12.2$ \\
\hline VSL & $76.8 \pm 6.0^{\mathrm{A}}$ & $72.7 \pm 6.7^{\mathrm{A}}$ & $75.3 \pm 8.4^{\mathrm{A}}$ & $76.8 \pm 5.8^{\mathrm{A}}$ & $71.3 \pm 6.4^{\mathrm{B}}$ & $79.3 \pm 9.2^{\mathrm{A}}$ \\
\hline VCL & $163.9 \pm 33.3^{\mathrm{A}}$ & $145.3 \pm 22.7^{\mathrm{B}}$ & $146.2 \pm 15.8^{\text {В }}$ & $173.9 \pm 26.3^{\mathrm{A}}$ & $142.9 \pm 25.4^{\mathrm{B}}$ & $154.2 \pm 27.1^{\mathrm{H}}$ \\
\hline ALH & $6.9 \pm 0.7^{\mathrm{A}}$ & $5.8 \pm 0.7^{\mathrm{B}}$ & $5.6 \pm 0.7^{\mathrm{B}}$ & $6.8 \pm 0.9^{\mathrm{A}}$ & $5.8 \pm 0.9^{\mathrm{A}}$ & $6.0 \pm 1.1^{\mathrm{A}}$ \\
\hline $\mathrm{BCF}$ & $25.3 \pm 4.5^{\text {В }}$ & $28.4 \pm 2.1^{\mathrm{AB}}$ & $31 \pm 3.7^{\mathrm{A}}$ & $24.9 \pm 3.6^{\mathrm{B}}$ & $27.5 \pm 3.6^{\mathrm{AB}}$ & $30.1 \pm 2.7^{\mathrm{A}}$ \\
\hline STR & $76.9 \pm 4.6^{\mathrm{B}}$ & $81.8 \pm 3.4^{\mathrm{AB}}$ & $83.7 \pm 3.9^{\mathrm{A}}$ & $76.2 \pm 5.4^{\mathrm{B}}$ & $81.3 \pm 5.6^{\mathrm{AB}}$ & $82.8 \pm 4.1^{\mathrm{A}}$ \\
\hline LIN & $47.0 \pm 4.1^{\mathrm{B}}$ & $52.8 \pm 3.7^{\mathrm{AB}}$ & $55.7 \pm 5.2^{\mathrm{A}}$ & $46.3 \pm 5.4^{\mathrm{B}}$ & $53.1 \pm 6.5^{\mathrm{A}}$ & $54.3 \pm 5.4^{\mathrm{A}}$ \\
\hline RAP & $62.5 \pm 13.8^{\mathrm{A}}$ & $68.6 \pm 8.3^{\mathrm{A}}$ & $67.1 \pm 9.1^{\mathrm{A}}$ & $62.5 \pm 11.9^{\mathrm{A}}$ & $65.9 \pm 8.5^{\mathrm{A}}$ & $64.8 \pm 10.7^{\mathrm{A}}$ \\
\hline PMI & $31.9 \pm 6.2^{\mathrm{B}}$ & $34.9 \pm 6.6^{\mathrm{B}}$ & $38.2 \pm 9.7^{\mathrm{A}}$ & $29.4 \pm 6.9^{\mathrm{A}}$ & $29.2 \pm 8.5^{\mathrm{A}}$ & $30.2 \pm 7.2^{\mathrm{A}}$ \\
\hline
\end{tabular}

TM (total motility $\mu \mathrm{m} / \mathrm{s}$ ), PM (progressive motility $\mu \mathrm{m} / \mathrm{s}$ ), VAP (average path velocity $\mu \mathrm{m} / \mathrm{s}$ ), VSL (straight-line velocity $\mu \mathrm{m} / \mathrm{s}$ ), VCL (curvilinear velocity $\mu \mathrm{m} / \mathrm{s}$ ), ALH (amplitude of lateral head displacement, $\mu \mathrm{m}$ ), BCF (beat cross frequency, Hz), STR (straightness, \%), LIN (linearity,\%), RAP (rapid cells), PMI (plasma membrane integrity, \%).

$(*)$ - different letters in the same line $(\mathrm{P}<0.05)$.

Source: Elaboration of the authors.

In a similar experiment, it was not seen any difference for VAP or VCL, and there was no significant interaction between stabilization time and the extender for both characteristics. The same occurred for VSL (FARRELL et al., 1996).

RAP did not differ $(\mathrm{P}<0.05)$ between the different types of stabilization keeping a satisfactory baseline. It is worth saying that the PMI in the extender B of the CR was better $(38.2 \pm 9.7 \%)(\mathrm{P}<0.05)$ than extenders $\mathrm{A}$ and $\mathrm{C}$. Despite such superiority, the
PMI was satisfactory regardless of the type of the stabilization method. In the present study the percentage of ruptured plasma membrane due to cryopreservation was higher than the percentage of motility loss, which is by the way in accordance with Salamon and Maxwell (1995). This demonstrates that the cryopreserved spermatozoa may still present movement and yet present membrane damage.

It was seen that the use of transport/refrigeration box, which is a system just like the one used by 
Malmgren (1998) and Farrás et al. (2008) provides higher transport security. Further studies shall be developed concerning the use of alternative semen transport/refrigeration systems in order to enable the use and accessibility of semen biotechnology regardless of the geographical region.

The findings in this experiment enable us to say that both commercial refrigerator (CR) and the transport/refrigeration box (TRB) were effective in keeping the viability of post-thawing bull semen. The transport box (TRB) is a good alternative to perform the whole semen refrigeration period when it is necessary the transportation of the samples until the laboratory facilities in which the material shall be processed.

\section{References}

BAILEY, J. L.; BILODEAU, J. F.; CORMIER, N. Semen cryopreservation in domestic animals: a damaging and capacitating phenomenon. Journal of Andrology, Stanford, v. 21, n. 1, p. 1-7, 2000.

CELEGHINI, E. C. C. Efeitos da criopreservação do sêmen bovino sobre a membrana plasmática, acrossomal e mitocondrial e estrutura da cromatina dos espermatozóides utilizando sondas fluorescentes. 2005. Tese (Doutorado em Medicina Veterinária e Reprodução Animal) - Curso de Pós-Graduação em Medicina Veterinária. Universidade de São Paulo, São Paulo.

CHACUR, M. G. M. Avaliação da congelação de sêmen bubalino com os diluidores Glicina-Gema, Tryladil $^{\circledR}$ e TES em diferentes tempos de equilíbrio. 1996. Dissertação (Mestrado em Reprodução Animal) - Curso de Pós-Graduação em Medicina Veterinária. Universidade Estadual Paulista, São Paulo.

CHACUR, M. G. M.; CASTILLO, A. M.; GUABERTO, M. L. Influence of the dry and rainy seasons upon plasma seminal (SDS-PAGE) and characteristics of the ejaculate from bulls (Bos taurus indicus). Semina: Ciencias Agrárias, Londrina, v. 32, n. 4, p. 1565-1574, 2011.

CHACUR, M. G. M.; OBA, E.; GONZALEZ, C. I. M. Equilibrium time influence on motility, vigor and membrane integrity of thawed buffalo semen using triladyl, glycine-egg-yolk and TES extenders. In: WORLD BUFFALO CONGRESS, 5., 1997, Caserta, Italy. Proceedings...Caserta, Italy: Roma, 1997. p. 846849.
CHACUR, M. G. M.; SIRCHIA, F. P.; RUIZ, A. C. L.; GUABERTO, M. L. Season influence upon seminal plasma proteins in Brown-Swiss bulls. Reproduction, Fertility and. Development, Nottingham, v. 22, n. 1, p. 310-311, 2010.

DAVID, B.; SERRES, C.; JOUANNET, P. Kinematics of human spermatozoa. Gamete Res., New York, v. 4, n. 2, p. 83-95, 1981.

DEIBEL, F. C.; SMITH, J. E.; CRABO, B. G.; GRAHAM, E. F. Evaluation of six assays of sperm quality by means of their accuracy, precision, and sensitivity in separating known induced levels of damage. In: INTERNATIONAL CONGRESS ON ANIMAL REPRODUCTION AND ARTIFICIAL INSEMINATION, 9., 1976, Crakow. Proceedings... Crakow: Poland, 1976. v. 4, p. 888-891.

FARRÁS, M. C. J. A.; AVANZI, B. R.; MELO, C. M.; DELLÀQUA, J. A; PAPA, F. O. Efeito de diferentes diluentes na manutenção das características do sêmen equino em dois sistemas de refrigeração passiva. Ciência Animal Brasileira, Goiânia, v. 9, n. 3, p. 693-699, 2008.

FARRELL, P. B.; FOOTE, R. H.; McARDLE, M. M.; TROUERN-TREND, J. L.; TARDIF, A. L. Media and dilution procedures tested to minimize handling effects on human, rabbit, and bull sperm for computer-assisted sperm analysis (CASA). Journal of Andrology, Stanford, v. 17, n. 3, p. 293-300, 1996.

FARRELL, P. B.; PRESICCE, G. A.; BROCKETT, O. C.; FOOTE, R. H. Quantification of bull sperm characteristics measured by computer-assisted sperm analysis (CASA) and the relationship to fertility. Theriogenology, London, v. 49 , n. 4 , p. 871-879, 1998.

FOOTE, R. H.; KAPROTH, M. T. Large batch freezing of bull semen: effect of time of freezing and fructose on fertility. Journal of Dairy Science, Champaign, v. 85, n. 4, p. 453-456, 2001.

GRAHAM, J. K. Response of spermatozoa to freezing. In: TECHNIQUES FOR HANDLING AND UTILIZATION OF TRANSPORTED COOLED AND FROZEN EQUINE SPERMATOZOA, 1., 1995, Colorado. Proceedings... Colorado, USA: Colorado State University Fort Collins, 1995. p. 83-95.

GRAHAM, J. K.; KUNZE, E.; HAMMERSTEDT, R. H. Analysis of sperm cell viability, acrosomal integrity, and mitochondrial function using flow cytomitry. Biology of Reproduction, New York, v. 43, n. 1, p. 55-64, 1990.

HARRISON, R. A.; VICKERS, S. E. Use of fluorescent probes to assess membrane integrity in mammalian spermatozoa. Journal of Reproduction and Fertility, London, v. 88, n. 4, p. 343-352, 1990. 
MALMGREN, L. Effectiveness of two systems for transporting equine semen. Theriogenology, London, $\mathrm{v}$. 50, n. 6, p. 833-839, 1998.

MORTIMER, S. T. CASA-practical aspects. Journal of Andrology, Stanford, v. 21, n. 4, p. 515-524, 2000.

SALAMON, S.; MAXWELL, W. M. C. Frozen storage of ram semen II. Causes of low fertility after cervical insemination and methods of improvement. Animal Reproduction Science, New York, v. 38, n. 1-2, p. 1-36, 1995.

SALVADOR, D. F.; ANDRADE, V. J.; VALE FILHO, V. R.; DIAS, J. C.; NOGUEIRA, L. A. G. Associação entre o perfil andrológico e a congelação de sêmen de touros da raça Nelore aos dois anos de idade, pré-selecionados pela classificação andrológica por pontos (CAP). Arquivo Brasileiro de Medicina Veterinária e Zootecnia, Belo Horizonte, v. 60, n. 3, p. 587-593, 2008.

SCHENK, J. L.; AMANN, R. P.; ALLEN, C. H. Effects of extender and insemination dose on post thaw quality and fertility of bovine sperm. Journal of Dairy Science, New York, v. 70, n. 7, p. 1458-1464, 1987.

WATSON, P. F. The causes of reduced fertility with cryopreserved semen. Animal Reproduction Science, New York, v. 60, n. 2, p. 481-492, 2000. 
